\title{
IMPROVING STUDENTS' READING COMPREHENSION OF DESCRIPTIVE TEXT BY USING RAINBOW CARD IN FEEDBACK STRATEGY
}

\author{
Rita Harisma ${ }^{1}$; Masitoh Nasution ${ }^{2}$ \\ English of Education, Universityof Muhammadiyah Sumatera Utara, Indonesia
}

Email : ritaharisma@umsu.ac.id

\begin{abstract}
This research was aimed to improving students' reading comprehension of Descriptive text by using Rainbow Card in feedback strategy. The subject of the study were the students of SMP Swasta AL-Hikmah Medan Academic Year 2019/2020. The research of this study was conducted by using classroom action research. The data used in this research were qualitative and quantitative data. The result of this research showed that there were increasing of students' reading comprehension. The mean of the pre-test was 44.6, in cycle one was 64.6, in cycle two was 80, it indicated that the scores and the mean in cycle two was better than the first one. In the pre-test of cycle one, there were not students who got point 70 . In the post test of cycle one the students who got point 70 or more there were 26 of students $(52 \%)$, it means that there were an increasing about $52 \%$. The post-test of cycle two, the students who got point 70 or more there were 42 students (84\%) and the increasing was about $32 \%$. The scores of observation sheet were 4 (very good). The students paid attention and also felt spirit in doing the reading test, and students more interested, enjoyed, and enthusiastic in doing the task by using feedback strategy.
\end{abstract}

Keywords: Reading Comprehension, Descriptive Text, Rainbow Card, Feedback Strategy

\section{INTRODUCTION}

Based on the preliminary observation and interview with the English teachers in SMP Swasta AL-Hikmah Medan, those factors also become problems of students. The first problem is related to the students' vocabulary mastery. The second problem is about the students' interest that affected their motivation. The students' problem in motivation can be seen from the condition who they were in the English reading activity. The last problem from the students is about their ability in implementing the reading strategies they know, as it was discussed before, it seems that the students did not use the reading strategy effectively.

Giving students feedback in classroom during the learning process has been proven to increase learning and improve students outcomes. When given correctly, feedback guides the students in their learning process and gives them the direction they need to reach the target or goal of the lesson. Feedback sends a massage to the students that the instructor cares about the learning taking place, it also allows the students to become more engage and involved in the classroom.

Based on the argumentation above, the researcher implements the Feedback Strategy to improving the seventh grade students' reading comprehension of SMP Swasta ALHikmah Medan.

In previous research by Karimshabani (2017) entitled The Effect of Content Feedback and Reading Strategies on Reading Comprehension: Extrovented and Introverted Learners. The researcher explain that there were some improvements of students' reading comprehension. and the role of feedback is another important point regarding the significant of teaching and is the process of evaluating the learner's performance to help them improve in areas that are needed so 
feedback can be a useful tool to help students to perform better.

Based on the background of the students in the school that the researcher found out the problems, so that the researcher analyze the improving students' reading comprehension of descriptive text by using rainbow card in feedback strategy in SMP Swasta AL-Hikmah Medan in Academic Year 2019/2020.

The researcher determined to make the improvement of reading comprehension by using rainbow card in feedback strategy for seventh grade students of SMP Swasta ALHikmah Medan in Academic Year 2019/2020.

Implementation and development of the seventh grade students of SMP Swasta AlHikmah Medan by using rainbow card in feedback strategy it can be increased the students' reading achievement.

\section{REVIEW OF LITERATURE}

\section{Reading Comprehension}

Reading comprehension is the process of making meaning from the text. The goal, therefore, is to gain on overall understanding of what is described in the text rather than to obtain meaning from isolated words or sentences. In understanding read the text information students develop mental models, or representations of meaning of the text ideas during the reading process. Van Den Boek \& Espin (2012 : 2), argues that "Reading comprehension is a complex interaction among automatic and strategies cognitive proceses that anables the reader to create a mental representation of the text".

\section{Factors that Influence Reading Comprehension}

There are many factors that might affect comprehension of printed materials. Some of the factors that will be explained here are characteristic of the materials, syntactical structure, and the appearance of print.
1. Vocabulary

e-ISSN 2621-010X

2. Concept of The Material

3. Syntactical Structure

4. The Appearance of Print

\section{Teaching of Reading}

Wallace (1992: 86) mentions that there are three stages in reading activities in the classroom as described bellow :

a. Pre-Reading Activities

b. While-Reading Activities

c. Post-Reading Activities

\section{Descriptive Text}

Descriptive text is a text which says what a person or thing is like, its purpose is to describe and reveral a particular person, place, or thing. In a broad sense, description, as explained by Kane (2000: 352), is defined like in the following sentence: Description is about sensory experience how something looks, sounds, tastes. Mostly it is about visual experience, but description also deals with other kinds of perception.

\section{Generic Structure of Descriptive Text}

When writing descriptive text, there are some generic structures (actually not mandatory) for our writing to be true. The arrangement is :

1. Identification

2. Description

\section{Purpose of Descriptive Text}

1. To describe person, thing or place in specific

2. To describe a particular person, thing or place

\section{Language Feature of Descriptive Text}

1. Specific participant

2. The use of the adjective (an adjective)

3. The use of simple present tense

4. Action verb

\section{Rainbow Cards}

Rainbow cards are the media that use in teaching reading a descriptive text to the students at junior high school, the teacher can 
use creative media to motivate the students in reading learning. Colour is a powerful design element that produces profound psychological and physiological reactions. (Mehta \& Zhu, 2009 in Ire Elvira, Havid Ardi, 2014), said that Colour is an important part of human perception. Many everyday objects have been designed to convey a message through colour.

\section{The Application of Rainbow Cards}

Media are kind of tools in teaching and learning process that can help researcher to be easier in explanation. Using media "rainbow cards" in teaching and learning process really helps researcher. The researcher should find appropriate topic to be taught with rainbow cards. All of cards have a meaning depend so that colour. So, in that cards researcher put the meaning of colour. There are some topics in teaching reading that can use this rainbow cards.

\section{Feedback Strategy}

Strategies have an important role in teaching and learning process which is used by the teachers who would like to be successful, especially English teacher in teaching English as foreign language. Karin Shabani (2017 : 18), argues that feedback is another important point regarding the significant of teaching and is the purpose of evaluating the learner's performance to help them improve in areas that are needed, so feedback can be a useful toll to help students to perform better.

\section{The Application of Feedback Strategy}

Susan M. Brookhart (2005 : 54) identifies the following are some of the most common ways to deliver oral feedback to a group or class:

1. At the start a lesson, summarizing your observations from the previous lesson

2. At the beginning of a review or reteaching lesson, to explain why you are focusing on the same learning target again and to link to prior learning and set a purpose for students
3. During students performances, either live or video taped

4. When a test or assigment is returned, summarizing overall strengths and weaknesses.

As stated early that this research tried to improve the students' reading achievement of descriptive text by using rainbow cards in feedback strategy. The classroom action research prosedure using Kurt Lewin's design consist of four four step within one cycle. Those are planning, acting, observing and reflecting.

\section{Planning}

Planning is the first step in action research. In this planning, the researcher makes some plans to choose actions that are feasible to be implemented in the field.

\section{Action}

Action is the implementation of the plans which have been arranged by the researcher, on the other hand action is guided by planning. All of the activities which are going to be done by the researcher in teaching and learning process are based on the lesson plan that have been prepared, and other material that can help the researcher in teaching and learning process there are some stages are going to appllied by researcher:

1. Pre-teaching (motivating strategies)

2. While-teaching

3. Post-teaching

\section{Observation}

Observation is an effort to recognize or observe the process, which happens during the teaching learning process, it is to find and obtain the development of the learning process and the effect of the action.

\section{Reflection}

In this activity, the researcher will have reflection based on the observation whether the research success or not. Then, the researcher reflects by seeing the result of the observation, 
whether the teaching learning process of reading in feedback strategy by using rainbow cards is good to imply in teaching and learning process or not, if the first plan is unsuccessful, proven by students' reading comprehension, the researcher will be continued to the next cycle to solve students' problem and to get the a better score.

\section{RESEARCH METHOD}

This research conducted at SMP AlHikmah Medan Jl. Marelan I Ps. 4 Barat No. 10, Rengas Pulau, Medan Marelan, Kota Medan, Sumatera Utara 20255. The population of the research is all of seventh grade, they are VII-1, VII-2, VII-3, VII-4, and VII-5. The subject is taken only one class is VII-1 which consists of 50 students.

This study was the classroom action research (CAR) prosedure, so the researcher used Kurt Lewin's design. Classroom action research is a reseach conducted by teacher in the classroom with the purpose to solve the students' problem in the classroom and repair performance of the teacher so that it can improve result of teaching and learning. Kurt Lewin (Kunandar, 2008:42) describes the prosedure of classroom action research into four steps. They are planning, acting, observing and reflecting.

The data collection were conducted by using observation sheet, interview, photography evidence and reading test.

This research applied qualitative and quantitative data :

1. The analysis qualitative data is used in this research observation of students' activities during teaching learning process, and the interview before and after Classroom Action Research (CAR) they are planning, acting, observing and reflecting.

2. The quantitative data there are reading test and it is 10 questions for each cycle. In scoring reading test, it is determine that the
Jurnal Serunai Bahasa Inggris

Vol 12, No. 2, Oktober 2020

e-ISSN 2621-010X

ranging from $0-100$ by accounting the correct answer. The correct answer has 1 point and incorrect answer gets 0 point and by applying this formula :

$\mathrm{S}=\frac{R}{N} \times 100$

Where :

$\mathrm{S}=$ score of the test

$\mathrm{R}=$ the number of correct answer

$\mathrm{N}=$ the number of question

To know the mean of the students' score of assesment will be given in each treatment, the resaerch will be applied the following formula : $\mathrm{X}=\frac{\sum x}{N}$

Where :

$X=$ the mean of students' score

$\sum \mathrm{x}=$ the total score

$\mathrm{N}=$ the number of the students

Based on the curriculum the students was expected reading comprehension in Descriptive Text learning in one meeting at least 7 questions, it meant that the students were expected to have correct answer at least 7 items of the test. That was appropriate passing grade of students at the school is 70 , so the categorize the number of the students who were competent in reading comprehension. the following formula was applied :

$\mathrm{P}=\frac{R}{T} \times 100 \%$

Where :

$\mathrm{P}=$ The percentage of those who get points up to 70

$\mathrm{R}=$ The percentage of those who get points up to 70

$\mathrm{T}=$ The total number of the student

\section{RESEARCH FINDING}

The result from data analysis indicated that there was an increasing on the students reading comprehension by using feedback strategy. The mean of the first cycle in pre-test were 64.6 it was good enough. The mean of second cycle in pre-test were 80 , it indicated that the scores and the mean in second cycle 
were better than the first cycle. The percentage of students who got point $\geq 70$ also grew up.In the post-test of cycle one (I) students who got point $\geq 70$ upwere 26 students (52\%) it means that there were an increasing about 52\%. The post-test of cycle two (II), students who got point 70 to up there were 42 students $(82 \%)$ and the increasing were about $32 \%$. In other words, the students' reading comprehension improved and became well in the first meeting to the next meeting.

The qualitative data were organized from the observation sheet, interview and photography evidence. All of these data indicated that the students gave their attitude and responses during teaching-learning process, it could be conducted that feedback strategy could improve students' reading comprehension especially for VII-1 grade students at SMP Swasta AL-Hikmah Medan.

\section{CONCLUSIONS}

The result of qualitative data showed, it could be concluded that the students responses were more active, spirit, enthusiastic and enjoyable in reading descriptive text by using feedback strategy and used rainbow card as learning media. From the result research analysis, it was found the improvement of students' reading comprehension was improve. The mean of post-test in cycle one (I) was better than pre-test and mean of post-test in cycle two (II) was better than post-test in cycle one (I). The percentage of students who got 70 up improved in each cycle, and also based on the finding stating that feedback strategy could improving students' reading comprehension.

\section{REFERENCES}

Blair, Heilman, Rupley. 2005. Principles and Practices of Teaching Reading. United States of America. A bell \& Howell Company.

Brookhart Susan M. 2005. How to Give Effective Fedback to Your Students. Wilson Web.

Duke, N. 2003. Comprehension instruction for informational text. Presentation at the annual meeting of the Michigan Reading Association, Grand Rapids, MI.

Grabe, W. 2009. Reading in a Second Language (Moving from Theory to Practice). New York: Cambrige University Press.

Harrison, C. 2004. Understanding Reading Development. London: SAGE Publication Ltd.

Hattie John, Helen Timperley. 2007. The power of Feedback. Review of Educational Research. 77.81-112.

Jos.E.Ohoiwutun, Nuriati, Mashuri. 2015. Improving Students' Reading Comprehension by Using Buzz Group Technique. E-Jornal of English Language Teaching Society (ELTS). $3.1-10$.

Kunandar. 2008. Langkah Mudah Penelitian Tindakan Kelas Sebagai Pengembangan Profesi Guru. Jakarta: PT Raja Grafindo Persada. 